\title{
NA CONCISÃO DE UM SONETO, O IMAGINARIO CAVALEIRESCO PORTUGUÊS
}

Lênia Márcia Mongelli*

RESUMO: O ensaio procura acompanhar a evolução do tema cavaleiresco, de concepção medieval, ao longo da Literatura Portuguesa. Momentos de apogeu e decadência são examinados paralelamente a fenômenos histórico-culturais. Tomase um soneto de Antero de Quental como ponto de partida para as reflexões.

Palavras-Chave: Crítica literária, ficção, medievalismo, renascimento, modernidade.

O soneto "O palácio da Ventura", de Antero de Quental (1842-1891), embora se refira a um dos aspectos cruciais da poética anteriana - a natureza intangível do Ideal, ainda mais quimérico se vinculado a projetos sóciopolíticos falidos, como os que fizeram arder entusiasticamente a geração oitocentista portuguesa - é um texto que ultrapassa seus próprios limites, para erguer-se como símbolo da realidade histórica lusitana e mesmo do Homem para além dela:

Sonho que sou um cavaleiro andante

Por desertos, por sóis, por noite escura,

Paladino do amor, busco anelante

O palácio encantado da Ventura!

Mas já desmaio, exausto e vacilante, Quebrada a espada já, rota a armadura.

$\mathrm{E}$ eis que súbito $o$ avisto, fulgurante

Na sua pompa e aérea formosura!

Com grandes golpes bato à porta e brado:

* Professora Titular de Literatura Portuguesa do Departamento de Letras Clássicas e Vemáculas, da FFFLCH/USP. 
Eu sou o Vagabundo, o Deserdado ...

Abri-vos, portas d'ouro, ante meus ais!

Abrem-se as portas d'ouro, com fragor ...

Mas dentro encontro só, cheio de dor,

Silêncio e escuridão - e nada mais!

O mundo aqui representado é onírico ("sonho"); mas todos os ingredientes que o estruturam estão fortemente atados à essência da cavalaria andante, tal como nos foi legada por estimulante junção, no século XII, de Verdade e Fantasia: o tema da busca (pelo "palácio encantado"), o da aventura infindável ("por desertos, por sóis, por noite escura"), o da persistência ("já desmaio"), o do espírito de luta ("quebrada a espada", "rota a armadura") e o do termo das andanças, que pode ser bem sucedido ("eis que súbito o avisto fulgurante") ou conduzir a fragorosa derrota ("... dentro encontro só, cheio de dor,/ Silêncio e escuridão - e nada mais!"). Guardadas as devidas proporções, esse é o esquema que todas as novelas cavaleirescas exploraram ad nauseam até que o gênero feneceu, sob a zombaria impiedosa de Cervantes no Quixote.

Com o soneto, Antero dava vazão à sua consciência dolorosamente dividida, de crente cético, de quem dá o melhor de si por causa sabidamente perdida. E é desse ângulo, o dos propósitos meio suicidas, que o texto enfoca graves e magnas questões, impregnadas no inconsciente coletivo português. Podemos começar pelo mito do heroísmo (o "paladino" de Antero), para o qual Joseph Campbell tem uma definição precisa: "Herói é alguém que deu a própria vida por algo maior que ele mesmo." Esse ato máximo pode realizar-se no plano da atividade física - como é o caso dos modernos superhomens dos quadrinhos e do cinema, ou no plano das realidades espirituais, quando se testam compromissos de natureza ética, de que a Bíblia traz numerosos exemplos - quem não se lembra de Isaac, de Sara, de Jó? Qualquer que seja a batalha, são necessárias coragem, destreza, generosidade e abnegação, porque é compulsiva a meta por atingir (ao preço da " própria vida") e condição intrinseca a necessidade de auto-superação ("algo maior que ele mesmo").

Esse modelo, por ser mítico, transcende a diversidade das diferentes culturas para erigir-se em essencialidade arquetípica, inscrevendo-se no tempo

1 Joseph Campbell. O Poder do Mito, trad. de Carlos Felipe Moisés, Associação Palas Athena, São Paulo, 1990, p.131. 
guês. Língua e Literatura, n. 22, p. 107-122, 1996.

de longa duração. E acarreta consigo comportamentos ritualísticos, destinados a reinterpretar o mito na sua exemplaridade intrínseca, todas as vezes em que fenômenos externos assim o exigem. Antropólogos ${ }^{2}$, sociólogos ${ }^{3} \mathrm{e}$ historiadores ${ }^{4}$ têm designado como "aventura do herói" o périplo desse ser especial, cujo papel decisivo é servir a comunidade ameaçada. O trajeto consta de três etapas fundamentais: 1. a partida para a aventura, que vem precedida por árduos treinamentos realizados ainda no anonimato da infância e da primeira juventude; 2 . o cumprimento da missão propriamente dita, a realização da tarefa superior, vedada ao comum dos mortais; 3 . o retorno vitorioso ao ponto inicial, acrescido do reconhecimento público, pois a sociedade de origem sente-se então libertada do peso que a oprimia. Nem é preciso dizer o quanto esse percurso, que descreve o círculo da perfeição, modelar nos contos de fadas ${ }^{5}$ tem atraído os psicanalistas atentos às mudanças profundas que as "passagens de nível" acarretam para a vida biológica e psíquica do indivíduo. E como tais "saltos" estão via de regra comprometidos com angustiantes processos de escolha e de decisão (em que Antero amargou seus dias), testes de resistência moral, resulta que a concepção do herói é acima de tudo ética, pondo em xeque a cada instante os valores do espírito.

Não há como distinguir heroísmo de epicidade, quer explícita, quer diluída nos interstícios da narrativa. E se, modernamente, a nossa concepção do épico ampliou-se, nos tempos clássicos as situações de guerra eram o palco ideal para que o herói fizesse valer sua bravura - quando menos porque a vida cotidiana impunha armar-se para defesa, fato com que a cristandade medieval teve de haver-se por, pelo menos, dez séculos. Para além dos quesitos usuais que a atividade bélica exige do guerreiro, da destreza à argúcia, da força à hombridade, antropólogos modernos como Roger Caillois ${ }^{6}$ vêm nas guerras movimentos coletivos do mesmo porte das grandes festas populares, tão cíclicas e tão renovadoras quanto elas, embora impliquem o lado negativo da morte. Ao ver de Caillois, é justamente a

2 Arnold Van Gennep. Os ritos de passagem, trad. de Mariano Ferreira, Petropólis, Vozes, 1978.

3 Jean Cazeneuve. Sociologia do rito, trad. de M.L. Borralho, Porto, Rés, s.d.

4 Principalmente os da linha da escola francesa dos Annales.

5 Bruno Bettelheim. A psicanálise dos contos de fadas, $3^{\mathrm{a}}$ ed., Rio de Janeiro, Paz e Terra, 1980.

6 O homem e o sagrado, trad. de Geminiano Cascais Franco, Lisboa, Edições 70, 1988, p.l61 e ss. 
consciência dolorosa da precariedade da existência trazida pelas guerras que faz delas um estranho e traumático momento de ruptura das interdições - quando o roubo, a rapina, o crime, a contemplação dos cadáveres, etc., ganham a banalidade do costume e a legitimidade das práticas de emergência sancionadas pelos poderes governamentais. $O$ desgaste é de tal ordem e o choque interior tão profundo, que o anseio de reconstrução das sociedades, após o holocausto, explica a intensa produtividade e a fartura dos interregnos de paz. Essa oscilação, constante desde a Antigüidade, foi examinada com precisão também no nosso século XX - considerado a "era dos extremos" por Eric Hobsbawm" - o qual chamou de "anos dourados" o intervalo entre as duas grandes guerras, a de 1914 e a de 1945. Apenas para encerrar o exemplo, segundo Hobsbawm, uma quebra econômica como a Depressão de 1929 teria tido outro andamento no seu processo de reconstrução, se este não fosse promovido por gerações de homens ainda sob o efeito impactante dos horrores da Primeira Grande Guerra.

Um olhar para trás, nesse panorama, distingue a Cavalaria, quer a histórica, quer a ficcional, como o campo privilegiado para o exercício do heroísmo, talvez porque medularmente atada ao motivo bélico, sua razão de ser. Instituição antiqüíssima, foi no período românico que ela ganhou o status com que se disseminou pelo mundo europeu, desbancando a infantaria, que tinha sido a estratégia militar preferida do Império Romano. Ao tempo da dinastia franca, principalmente no período carolíngio - momento da proliferação das canções de gesta - a agremiação sacraliza-se, tanto pela severa ritualizaçao dos laços de vassalidade, quanto pelas vantagens econômicas acrescidas da concessão ao iniciado de bens e terras da Igreja ${ }^{8}$ Com o advento das Cruzadas, nos séculos XI e XII, aparece a extraordinária figura do "monge guerreiro", numa complexa aliança do sagrado e do profano que tem feito as delícias dos historiadores das religiões.

A prevalência quantitativa das novelas de cavalaria sobre as epopéias no transcurso da Baixa Idade Média, embora ambas as fôrmas assentem no substrato comum do heroísmo às voltas com interesses e finalidades coletivas, grupais, explica-se não só por condições gerais favoráveis (incremento do comércio e fortalecimento da burguesia nascente, criação das

7 Eric Hobsbawm. Era dos extremos - o breve século XX, trad. de Marcos Santarrita, São Paulo, Companhia das Letras, 1995.

8 F.L.Ganshof. Que é o feudalismo? Trad. de Jorge Borges de Macedo, $3^{a}$ ed., Lisboa, Europa-América, 1974. 
guês. Língua e Literatura, n. 22, p. 107-122, 1996.

universidades, desenvolvimento das cidades, formação das línguas nacionais, etc.), como pela conformação do princípio de individualismo anunciador das profundas reformas quinhentistas. $\mathrm{O}$ herói medieval combate por seu rei e pela pátria, mas o faz também por si mesmo, selando conscientemente sua Sorte e buscando a salvação da alma.

Talvez seja por peculiaridades tais, dentre tantas outras, que as novelas de cavalaria caíram no gosto popular preferentemente às epopéias, revisitadas e revigoradas apenas a partir do Renascimento quinhentista. Os ingredientes novos que a ficção cavaleiresca traz para o mundo da criação literária, com o inegável contributo da mitologia céltica e do imaginário folclórico, a criar símbolos polissêmicos de situações humanas fechadas e irreversíveis, permitiram a Joseph Campbell, por exemplo, considerar Persival, de Wolfram von Eschenbach (composto por volta de 1210), obra mais densa e mais significativa para sua época do que a própria Divina Comédia, de Dante Alighieri ${ }^{9}$

Sem aderir ao entusiasmo um tanto hiperbólico de Campbell, havemos de convir que um texto como $A$ Demanda do Santo Graal (versão portuguesa do século XV de originais franceses de possivelmente 1220) faz jus não só à elevada estima do eminente historiador, como ainda fundamenta a eleição popular, cujos critérios intuitivos Giambattista Vico distinguiu e exaltou na sua Ciência Nova ${ }^{10}$ Será que bastariam temas excitantes como o do Graal, o da Távola Redonda, o da corte principesca de Artur, o do amor pecaminoso entre Lancelot e Ginevra, o da castidade de Galaaz, o da traição de Morderet, etc., para sustentar a extraordinária acolhida que a obra teve desde sua composição? A proliferação da "matéria de Bretanha" por no mínimo dois séculos, insistindo nesses mesmos motivos plenos de significados esotéricos, faz pensar que a atração da obra não advém da vertente espetaculosa e plurifacetada de sua matéria-prima. $\mathrm{Na}$ verdade, o segredo da Demanda está na tensão - em alguns episódios levada às últimas conseqüências - entre os apelos individuais e a ordem social, entre os deveres de homem e os de cidadão, entre os impulsos da carne e os do espírito. São as encruzilhadas, os impasses, os becos-sem-saídas, cuja extensão espacial se metaforiza nas florestas sombrias, nos bosques traiçoeiros e nos caminhos duplicados, que emblematizam o estado de dívida de nossa humani-

9 As transformações do mito através do tempo, trad. de Heloysa de Lima Dantas, São Paulo, Cultrix, 1990, p.197 e ss.

10 Giambattista Vico. Principios de una Ciencia Nueva, trad. y prologo de José Camer, México, Fondo de Cultura Economica, 1987. 
dade imperfeita, falível, tentando incertamente acertar através do erro (o que talvez tenha levado Antero ao suicídio).

Aí está o modelo arquetípico que subsistiu até à modernidade. A idéia da meta a ser atingida através de duras provações, das quais se sai com a alma lavada e suficientemente amadurecida para gozar o prêmio prometido e viver na bem-aventurança, serve igualmente a causas religiosas e a causas políticas (veja-se o soneto transcrito), a ambições econômicas ou científicas - enfim, a qualquer projeto de vida, utópico ou não, de matiz escatológico.

Não é o que tem feito a Literatura Portuguesa ao longo de sua história, como parece propor indiretamente o poema de Antero de Quental? Quando se afirma que Portugal não teve Idade Média, pelo menos com a configuração ortodoxa de uma França ou de uma Inglaterra, nem por isso os quatro primeiros séculos de nascimento e infância deixaram de compor aquela "ambiência lendária" que Fidelino de Figueiredo considerou indispensável à eclosão do épico ${ }^{11}$, por ele situada, e com razão, no século XVI. Foi a Idade Média portuguesa dos primeiros séculos que nos legou a gesta de Afonso Henriques, o cavaleiro heróico da Independência. Embora sejam escassos os textos que recolheram as façanhas cavaleirescas do $\mathrm{Rei}^{12}$, episódios como a rebeldia contra a Santa Sé de Roma, punida com a excomunhão; contra a própria mãe, presa por lhe ameaçar os planos, e mais o famigerado milagre de Ourique, que trouxe Deus em pessoa para a facção dos lusitanos, já deixavam antever os "anos dourados" do Renascimento, quando os portugueses se fizeram ao mar como cavaleiros andantes, protegidos pelo mesmo Céu que abrigara Afonso Henriques.

De fato, naqueles primórdios delineou-se o pendor aventuroso da gente lusa (a que Antero de Quental não ficou imune); e a instalação no trono, mais tarde, da dinastia de Avis, com os rigores metodológicos de D. João I e de D. Philipa de Lencastre, garantiu o aprimoramento de ademanes cavalheirescos, em moda na Europa empenhada na educação dos príncipes. Se razões sócio-político-econômicas, que não cabem aqui historiar, tornam plausível a feição medievalesca do Renascimento português, ela acentua-se sobremaneira pela absorção que a empreita dos Descobrimentos fez dos ideais da Cavalaria. Não só as viagens transoceânicas mantêm uma rela-

11 Fidelino de Figueiredo. A épica portıguesa no século XVI, São Paulo, Boletim da FFLCH, 1950.

12 Antonio José Saraiva, A épica medieval portuguesa, Amadora, INL/MEC, 1979. 
ção sinedóquica com o arquétipo da aventura, como a maneira de vivê-las ressuma, no dizer de muitos, a "provação" Para ficarmos apenas com um testemunho de época, cite-se a Peregrinação, de Fernão Mendes Pinto: apesar de comprovadamente fantasiar os fatos históricos, documenta soberbamente os imprevistos da travessia rumo a Oriente, com o anseio de vitória justificando desmandos e acertos, generosidade e injustiça, medos, superstições e felonias - numa contínua tensão em tudo análoga à vivida pelos vassalos de Artur ávidos do Graal.

De um ponto de vista bem particular, mas apoiado criticamente pelas tendências da Nova História ou da chamada "história das mentalidades" de extração francesa, pode-se dizer que o heroísmo do século XVI em Portugal estaria parcialmente representado - embora de forma sublime se contasse apenas com Os Lusíadas. Por mais que Camões tenha inovado o modelo, enxertando nele as severas admoestações contra a ganância dos navegantes ou concebendo a esplêndida convivência do humano com o divino na Ilha dos Amores, a racionalidade e o equilíbrio da epopéia colidiriam com os desmedidos vôos da fantasia patrocinados pelas novelas cavaleirescas. E como a época é de euforia e desregramentos hedonistas, cujas terríveis conseqüências Antonio Sérgio ainda lamentará no século $\mathrm{XX}^{13}$, parecem legítimos os excessos sensuais de Floriano do Deserto no Palmeirim de Inglaterra (1544), a monumentalidade principesca do torneio de Xabregas n'O Memorial das proezas da segunda Távola Redonda (1567) ou o desmaio providencial do Sábio Fanimor, que perde a fala ao vaticinar a grandeza reservada aos portugueses, na Crônica do Imperador Clarimundo (1520).

Digamos que nas novelas de cavalaria, que nacionalizaram o gênero no Portugal quinhentista, o teor hiperbólico das narrativas, abertas ao fantástico e ao absurdo, seqüência infindável de episódios mirabolantes, espelha - talvez com mais fidelidade do que outra forma qualquer - o mito da aventura expansionista no imaginário popular. Uma vista d'olhos sobre a História trágico-maritima, com seu rol de perdas e danos, humanos e materiais, tão belamente cantados por Fernando Pessoa em Mensagem, justifica, no plano ficcional, a severa educação imposta ao jovem Clarimundo, que precisa treinar o corpo e o espírito para reinar sobre tão brava gente, capaz de morrer nos oceanos do mundo. Matar gigantes monstruosos aos doze anos

13 Antonio Sergio. Breve interpretação da História de Portugal, 24 ed., Lisboa, Sá da Costa, 1972. 

guês. Língua e Literatura, n. 22, p. 107-122, 1996.

de idade ou vencer, em luta de peito aberto, as artimanhas mágicas de bruxas e feiticeiros, são alegorias com forte ressonância, ao ver do homem comum, na realidade fenomênica dos portugueses renascentistas (do que parece ter-se dado conta Antero de Quental).

Como se sabe, as novelas de cavalaria, fôrma medularmente atrelada ao feudalismo medieval, fizeram sua última aparição no cenário europeu durante o século XVI e, no mais tardar, no século XVII, apesar do anacronismo dessa erupção. Mesmo em Portugal, onde havia fortes razões para explicar os frutos serôdios, o gênero esfumou-se. E o heroísmo que vingou foi o de matiz camoniano, epigonal, cujo mais rumoroso representante foi o polêmico José Agostinho de Macedo, que compôs o poema épico $O$ Ocidente (publicado em 1814) com o objetivo declarado - e frustrado - de destronar Os Lusiadas. Posto o quê, só com o Romantismo a Cavalaria ressurgirá, recebendo o sopro alentador de Hegel, que a considerou palco ideal para a representação do amor, da honra e da lealdade - motivos restaurados pela subjetividade romântica ${ }^{14}$

A transição do século XVIII para o XIX, de mudanças tão profundas quanto as que viveu o homem medieval na virada dos séculos XI/XII ou o homem clássico na passagem do XV ao XVI, obriga-nos, do ponto de vista aqui abordado, a duas reflexões essenciais: 1. segundo os teóricos do gênero, o épico construiu-se através da epopéia, das canções de gesta e das novelas de cavalaria. Simplificando ao maximo a questão, é de considerar que não somente a epopéia clássica sobrevivesse transubstanciada no romance moderno, mas também que a prosa de ficção em geral, emergente na era romântica, se deixasse impregnar por aqueles valores gésticos e cavaleirescos elevados ao plano das chamadas "invariantes históricas" ou míticas; 2 . no caso especificamente português, é de considerar também que a saga dos Descobrimentos ficou sendo o reservatório épico da nação para a posteridade, ponto de referência indispensável, direto ou indireto, da ficção subseqüente, quer para enaltecer o período, quer para detratá-lo. No mar projetou-se a grande metáfora do heroísmo bélico português, que absorve, por extensão, todo o passado histórico lusíada, gênese da aventura expansionista. Fernando Pessoa, como sempre, disse-o de forma lapidar, pela voz de Álvaro de Campos: "Pertenço a um gênero de portugueses/ Que depois de estar a Índia descoberta/ Ficaram sem trabalho"1s

14 "A arte romântica" Estética, trad. de Orlando Vitorino, 2a ed., Lisboa, Guimarães Ed., 1972, vol.IV. (V. principalmente o capíltulo "A cavalaria", p.229-264).

15 "Opiário". Obra poética, Rio de Janeiro, Aguilar, 1960, p. 258. 
Desse ângulo, o Romantismo cristaliza na Literatura Portuguesa um momento de especial convergência dos valores cavaleirescos medievais $\mathrm{e}$ do heroísmo quinhentista, que se fizeram representar pelas novelas de temas históricos, postas em voga pelos ingleses. Conquanto a exaltação das origens pátrias e a defesa acirrada da liberdade e dos valores nacionalistas tenham sido a tônica dos movimentos reformistas que, na primeira metade do século XIX, assim manifestavam sua euforia pós-Revolução Francesa ${ }^{16}$, Portugal acresceu ao entusiasmo geral a convicção de poder restaurar o esplendor do Renascimento e a esperança de emergir da forte depressão causada pelo nunca suficientemente lamentado domínio filipino a partir de 1580. O curto período da chamada "união ibérica", atestado público da humilhação imposta ao lusitanos ${ }^{17}$, não foi superado nem pelo sangue novo injetado ao tempo de D. João $\mathrm{V}$ e do ouro brasileiro, nem pela viril e inovadora administração pombalina. A impessoalidade da literatura setecentista, com seu estrangeirado jargão arcádico, bem espelha o atrofiamento da criatividade lusa, como que desconfiada de si mesma.

Olhar o passado estimulado pela decadência presente fez reacender antigas paixões e o anseio de recuperar o paraíso perdido (estaria ele no espírito de Antero?), que é como se afigurou à coletividade a grandeza pretérita de Quinhentos ${ }^{18}$. As Viagens na minha terra, de Almeida Garrett (1843), escritas no calor da militância e da combatividade de seu autor, são a apologia declarada do "símbolo", do "mito", segundo suas próprias palavras no capitulo II: a obra ergue-se como "a crônica do passado, a história do presente, o programa do futuro" 19 Se a "história do presente" descreve a luta pelo poder entre cartistas e liberais, a "crônica do passado" está escrita no "livro de pedra" de Santarém, berço da nacionalidade lusíada, onde os "barões assinalados" deixaram para a posteridade a marca de seu heroísmo. Segundo Garrett, Camões viu bem essa diferença essencial: " 0 italiano tinha fé em Deus, o alemão no ceticismo, o português na sua pátria"20.

16 René Rémond. O século XIX - 1815/1914, São Paulo, Cultrix, 1976.

17 Os mitólogos costumam apontar a queda após o apogeu como um motivo de densas implicações religiosas como pecado, castigo, culpa, expiação, etc. (V. especialmente as obras de Mircea Eliade e Joseph Campbell).

18 Recorde-se que é exatamente este o andamento de Mensagem, de Fernando Pessoa, onde a função da parte $I I$, referente aos feitos marítimos, é servir de modelo às críticas expostas na parte III.

19 Almeida Garrett. Viagens na minha terra, $2^{a}$ ed., Porto, Livraria Chardron, s/d, vol. I, p.12.

20 Idem, p.35. 

guês. Língua e Literatura, n. 22, p. 107-122, 1996.

Exemplo tão ou mais contundente oferece a obra ficcional e historiográfica de Alexandre Herculano, paladino da cavalaria romântica portuguesa. Em Eurico, o Presbitero (1844), o padre atormentado pelo conflito entre a fé e a paixão, com a Pátria de permeio, compõe o delicioso ângulo romanesco da narrativa. Pode-se dizer que Eurico é a versão oitocentista de Tristão, de Lancelot, de Abelardo e de outros heróis medievais que se viram prensados entre a razão e o coração e que se serviram das armas inclusive como estratégia suicida para descarregar a tensão. No caso de Eurico, a morte, fuga romântica, selou a lhaneza do caráter arquetipicamente concebido.

Como essa tendência medievo-humanística do Romantismo português veio de encontro à contextura mais íntima da psique nacional, potencialidade anunciada desde Afonso Henriques, seus ecos são duradouros e varam o século XIX, contra a propalada iconoclastia da "geração coimbrã" (não se perca de vista o soneto e a propria biografia de Antero). Quem haveria de supor que, já quase ao fim de sua produtiva carreira de implantador do Realismo em Portugal, Eça de Queirós comporia a estupenda figura de Afonso da Maia (Os Maias, 1888), contraponto da abulia e do ócio burguês, cheio de uma soberba heráldica diariamente realimentada na galeria dos antepassados heróicos? E o que dizer, ainda, de Gonçalo Mendes Ramires (A Ilustre Casa de Ramires, 1900), enfurnado na memorável Torre de seu castelo semi-arruinado, tão decadente quanto ele, a redesenhar a árvore dos Ramires e a colorir imaginosamente o velho paço de Santa Irinéia, do século XII? São personagens cavaleirescas como Eurico, embora sua constituição anímica espelhe por inércia a herança atávica, talvez por força da ambientação numa sociedade finissecular decadente (que parece ser a atmosfera do soneto citado).

O que se observa, então, desse rápido panorama, é que a sociedade oitocentista portuguesa retomou, para acentuá-la - e até exacerbá-la, como era próprio de seu temperamento, capitaneado por Antero de Quental - a vertente idealista da temática cavaleiresca, com evidente predileção pela porção brumosa da "matéria de Bretanha", direcionada para a pujança metafórica da era dos Descobrimentos. O olhar que pousa no presente e no passado exerce função eqüidistante: quanto mais se acirra a crítica ao momento e ao homem contemporâneo, frustrado com o malogro das causas liberais e às voltas com remanescentes absolutistas que teimam em permanecer; quanto mais as teorias politico-econômicas tentam justificar e denunciar as disparidades sociais; quanto mais a marcha do progresso vai 
anunciando, paradoxalmente, a falência de anseios que culminam no humilhante Ultimatum, tanto mais a consciência coletiva, fragilizada, se refugia nas glórias distantes, no heroísmo de antanho, nas vitórias sobre o mar como se importasse não perder a confiança na "raça" hercúlea, testada e bem sucedida em Quinhentos. Não é a tese defendida em Mensagem, de Fernando Pessoa?

Mas o "cavaleiro" de agora é tíbio, frouxo, ocupado antes com sonhar do que com agir, capaz de propor modelos e não soluções, falto de finalidades e de metas por cumprir - vagante sem rumo e sem causa, como aqueles filhos segundos da nobreza feudal, que maculavam a instituição cavaleiresca e que motivaram Urbano II a propor a primeira Cruzada, maneira legal de congregar esses dispersos em torno de interesses comuns. Todos os projetos de Gonçalo Mendes Ramires estão apoiados, de alguma maneira, em parâmetros genealógicos; só que não se concretizam, como a infindável novela sobre os feitos grandiosos de Tructesindo Ramires. No extremo da apatia e da inação, Eça de Queirós inventa, com cinismo, bom humor e muita melancolia, Fradique Mendes, o moderno voyer que perdeu o sentido do sagrado.

Ocupando uma incômoda posição intermediária no tempo, entre o passado e o futuro, esses arremedos de "cavaleiros" sobrevivem de escudarse na Idade do Ouro, na utopia de grandezas perdidas e na fé de tentar recompô-las, de readquirir o estado beatífico original. $\mathrm{Na}$ polaridade das intenções está o substrato do que os antropólogos costumam classificar de "mitologia escatológica", assentada no paradigma bíblico, que "projeta no futuro mais distante o mito do passado primevo"21 À medida que se vai aproximando do século XX, rompe-se o equilíbrio da oscilação passado/ futuro e a ausência de perspectivas erige uma cavalaria espectral, que não hesita em lançar mão do escárnio para ridicularizar heroísmos inúteis e para rir de si mesma. N'O Cavaleiro inexistente, de Italo Calvino, a armadura vazia do protagonista, Agilulfo Emo Bertran Dino dos Guildiverni e dos Altri de Corbentraz e Sura, será talvez a mais eloqüente metáfora do Nada a que se condenou o combatente sem patrocínio, sem causa e sem amanhã. Então, que venha o deboche da "armata Brancaleone"!

Os portugueses contemporâneos, em que pese à sua veia cômica, não são capazes de brincar assim com coisas tão sérias (Antero menos ainda). $\mathrm{O}$ reexame que se propuseram fazer da tradição diagnostica antes

21 Raphael Patai. O mito e o homem moderno, São Paulo, Cultrix, 1974, p.79. 

guês. Língua e Literatura, n. 22, p. 107-122, 1996.

miséria que fartura e vê no esplendor antigo a gênese da queda, marasmo de que urge despertar ("Valete, Fratres", convoca Fernando Pessoa). A chamada "meta-história", na classificação de teóricos como Hayden White, que defende o inextricável embricamento de História e ficção, parece ter estimulado escritores como Lídia Jorge, José Saramago, Almeida Faria, António Lobo Antunes e tantos mais à desmitificaçao da memória nacional. Às vezes com a irreverência de um António Sergio, para quem El-Rei D. Sebastião foi um "inexcedivel pedaço de asno" 22 e que reavalia, com intransigente rigor, a reversão da marcha histórica: "... se olharmos o nosso passado, ver-se-á que até o fim do Quinhentismo Portugal acompanha galhardamente o melhor espírito europeu, a mentalidade dos povos cultos; então, pode-se dizer que ele está na Europa, e a muitos respeitos na vanguarda dela; mas depois... Depois, desde essa data, o facho apaga-se; e o que se vê posteriormente é o estacar (o cair de golpe) desse Portugal do Renascimento. O espírito português do Quinhentismo foi promessa que se não cumpriu. Dá-nos a impressão de um adolescente, talentoso e prometedor, a quem uma doença do sistema nervoso viesse arrancar subitamente os dotes físicos e mentais. Passa-se do Reino da Inteligência - para o Reino da Estupidez"23 Segundo José Sebastião da Silva Dias, mesmo esse anterior "reino da Inteligência" é bastante discutível, porque muitas das instituições culturais portuguesas ainda se guiavam, então, pelo escolaticismo medieval, em franco contraste com o poderio econômico e os avanços técnicos trazidos pela Expansão ${ }^{24}$

$\mathrm{E}$ ao ver desses severos juízes, se o conturbado e belicoso século XX prometia alvíssaras de alguma mudança, mais uma vez ela se auto-negou com a famigerada Revolução dos Cravos de 1974, que nada mais fez do que revelar ao mundo os desastrosos efeitos de quase cinqüenta anos sob regime político ditatorial, anestesiador das consciências. Os habitantes de Vilamaninhos, em $O$ dia dos prodígios, de Lídia Jorge, cuja vida rudimentar semelha o primitivismo da Idade da Pedra, mal ouvem os ecos da Revolução, incapaz de sacudi-los da alienação secular.

Esse estado de coisas foi modelarmente emblematizado por Almeida Faria em Cavaleiro Andante (1983), último volume de uma tetralogia ( $A$

22 "Interpretação não romântica do Sebastianismo" Ensaios, $2^{a}$ ed., Lisboa, Sá da Costa, 1976, vol.I, p.241.

23 "0 reino cadaveroso ou o problema da cultura em Portugal". Ensaios, idem, vol.II, p.27.

24 V. principalmente o capítulo I de Os descobrimentos e a problemática cultural do século $X V I$, Lisboa, Ed. Presença, 1982. 
guês. Língua e Literatura, n. 22, p. 107-122, 1996.

Paixão, 1965; Cortes, 1978; Lusitânia, 1980), que acompanhou, com minúcia de laboratorista, a decadência e dispersão de um clã do Alentejo, sediado em Montemínimo e chefiado pelo morgado Francisco, marido de Marina e pai de André, João Carlos, Arminda, Jó e Tiago. Sem o saudosismo de Aquilino Ribeiro em A casa grande de Romarigães (1957) e sem as nuanças nostálgicas de José Régio na série $A$ velha casa, o romancista serve-se impiedosamente dos azares dessa família como metonímia do Portugal pósrevolucionário, onde a falta de perspectiva e a estreiteza dos horizontes parece ter mudado apenas quanto à forma exterior de representação. Todos os signos da fiç̧ão cavaleiresca são tratados aqui as avessas, na esteira do desânimo que fecha o soneto de Antero de Quental: a combatividade heróica apagou-se na inação de Francisco, morto ingloriamente por seus próprios empregados revoltados, rebelião vassálica contra dominação ainda de estilo feudal; a amedrontada e pusilânime Marina é cópia-carbono de apaixonadas altivas como Guinevére e Isolda, capazes de arrostar o mundo para fazer valer seu amor; e as "aventuras", honroso lazer para os membros da Távola Redonda sequiosos de "provar-se", são andanças angustiosas porque pautadas pela abulia dos que não têm direção. Em carta para a mãe, André despede-se: "Para ti o muito amor do teu cavaleiro andante, como me alcunhavas por andar sempre fora de casa. Tanto andei que desandei, até que tresandarei." ${ }^{25}$. Aventurar-se, então, para os membros do clã alentejano, não é movimento prospectivo, não é investimento no futuro, pois é retroativo, é fuga dos fantasmas da infância, da opressão familiar e de transformações ininteligíveis. Os cavaleiros de Almeida Faria, que não viram e nem verão o Santo Vaso, caminham para trás, estigmatizados pelo passado morto-vivo. Di-lo André, e suas palavras sintetizam a roupagem moderna de que se travestiu o arquétipo graalesco: "Alguém escreveu que os mortos são felizes, andam dispersos pela imensa natureza, pela infinita matéria, enquanto nós, os vivos, ruidosos, noturnos, inquietos, sofremos presos de quimeras, encarcerados nestas cidades, sem razão, sem sentido senão sobreviver ou ir sobrevivendo."26 - texto muito similar à negatividade lírica de Antero, o "Vagabundo", o "Deserdado"

Da coragem ao medo, da persistência ao recuo, do movimento à estagnação, das certezas às dúvidas, a Cavalaria estraçalha-se nesse jogo de opostos, com a própria natureza do discurso denunciando o anacronismo e a

25 Almeida Faria. Cavaleiro Andante, Rio de Janeiro, Nova Fronteira, 1987, p. 102.

26 Idem, p.103. 

guês. Lingua e Literatura, n. 22, p. 107-122, 1996.

inadequação do modelo num século XX que, dentre outros propósitos terríficos, na opinião de Eric Hobsbawm, convive com a diária ameaça do holocausto nuclear. ${ }^{27}$

E eis a questão: se a Cavalaria se tornou motivo fantasmagórico em tempos que a rejeitam, o que terá levado autores como Eça de Queirós, Antero de Quental a sonhá-la ou como Almeida Faria a reerguê-la por antítese? Que elos se mantiveram constantes em Portugal entre o século XII e o XX, a falar por uma espécie de mítica cavaleiresca? Hilário Franco Júnior formula a mesma pergunta, em $A$ Eva Barbada, a propósito do inesperado reaproveitamento que as sociedades medievais cristãs fizeram de mitos pagãos por elas mesmas ardentemente condenados. A resposta passa pela ritualização necessária de procedimentos antigos: "É verdade que o mito abole o tempo histórico e que o rito ciclicamente leva seus participantes àquele momento indefinido. Mas ao mesmo tempo o rito representa o mito, isto é, torna-o novamente presente, torna-o contemporâneo dos que dele participam. Mito e rito não existem na sua atemporalidade intrínseca, mas na historicidade que lhes dá sentido, e à qual eles próprios dão sentido." E mais adiante: "É preciso considerar que mito não é história dos eventos políticos ou econômicos, mas história da sensibilidade coletiva. É expressão da longa duração histórica, expressão de valores fortemente enraizados, daí a larga permanência de um relato mítico, permanência, contudo, sujeita a flutuações decorrentes das condições históricas concretas." Por último: "Se era possível transformar a cerimônia dos sacrifícios pagãos em oferendas cristãs é porque entre ambas havia uma estrutura comum"28. Qual será ela, essa "estrutura comum" entre a novela de cavalaria quinhentista de nacionalidade portuguesa e os seus remanescentes posteriores, até o retrato-emnegro de Almeida Faria, como parece ressoar do soneto anteriano?

Por resposta, acrescente-se uma última reflexão. A Literatura que se faz em Portugal no século XVI, científica, filosófica ou ficcional, é toda ela eivada de ufanismo, alimentado por sucessivas conquistas que se foram somando desde meados do século XV e fortalecendo a sensação de domínio da Natureza e de superação dos antigos. Contudo - e eis o nó - tão notória quanto essa vertente é a outra face da moeda, a voz paralela que clama contra os desmandos, contra os gastos excessivos e os desvarios da ambição. Não só as palavras poderosas e emblemáticas do Velho do Restelo

27 Eric Hobsbawm, op. cit. (V. de preferência o capitulo intitulado "Rumo ao milênio").

28 Hilário Franco Junior. A Eva Barbada, São Paulo, Edusp, 1996, pp. 47 e 49, respectivamente. 
guês. Língua e Literatura, n. 22, p. 107-122, 1996.

condenam "a glória vã, a vã cobiça de mandar" dos navegantes ávidos de aventuras; também nas novelas de cavalaria, aproveitando seu intuito pedagógico e a voga da educação da nobreza, acumulam-se os epifonemas sentenciosos, cada episódio arrematado por verdadeiro doutrinário moral, sempre alertando para o caráter transitório do poder e o falso ouropel das riquezas. No capítulo III do Memorial das proezas da segunda Távola Redon$d a$, diz o narrador: "Errado fundamento he ho dos Reys, que desamparando o próprio estado por ir conquiistar ho alheyo, occasiam muitas vezes de perderem ambos, ou gaynhar perpetua infamia, e muito peor fim" 29

De todos os lados ecoam avisos como esse, de olhares atentos por entre a ofuscação das vitórias e temerosos do declínio que se anunciava simultaneamente à ascensão e que teve seu arremate nada surpreendente em D. Sebastião e Alcácer-Quibir. Aquela "gente surda e endurecida" era derrotada enquanto crescia, prenúncio dos paradoxos barrocos que mergulharão em trevas o período seguinte. Nesse cenário, a ficção cavaleiresca manifesta-se por dupla função: não só ela alegoriza a realidade presente em sua faceta grandiosa, como sugere o componente ilusório de sua mundividência, com ser anacrônica e propor ideais inalcançáveis (dualidade que Antero captou com agudez). De experimentalismos mas também de quimeras alimentaram-se os cavaleiros que buscavam o caminho marítimo para as Índias; quando o fiel da balança se rompeu e o equilíbrio se desfez, o Império ruiu. O retorno desses heróis à imaginação popular, na primeira metade do Século XIX, dá-se agora através de mitos, de matiz saudosista, a falar por uma situação histórica que não conseguiu recuperar o esplendor do passado. O cavaleiro oitocentista já é figura quase caricata, tais os exageros com que o concebem. Insistir num heroísmo que, frente às circunstâncias, parece cada vez mais falso, é o que fará rir posteriormente a modernidade.

No passado ou no presente, a ficção cavaleiresca em Portugal constrói-se sob o signo da UTOPIA (disse-o liricamente Antero): no princípio, porque os limites por conquistar eram sempre mais atraentes do que os conquistados ("se mais mundos houvera, lá chegara", vangloriou-se Camões); depois, porque as vitórias estiveram muito aquém dos sucessos antigos. O cavaleiro andante avulta como imagem perfeita dessa procura sem fim, que não se confunde com algum "mero objeto de desejo: enquanto

29 J.F. de Vasconcelos. Memorial das proezas da segunda Távola Redonda, Lisboa, tip. Panorama, 1867 , p.6 
122 MONGELLI, Lênia Mårcia. Na concisão de um soneto, o imaginário cavaleiresco português. Língua e Literatura, n. 22, p. 107-122, 1996.

este é individual, visível, concreto, substituível, se esgota pela satisfação, o objeto da utopia é coletivo, etéreo, transcendente, permanente, se realiza pela busca." 30 . Esse herói especial, desconfiado do descompasso entre a própria força e o fim em mira, prefere a ilusão à verdade porque é muito mais potência do que ato. "Silêncio e escuridão", na voz de Antero.

ABSTRACT: The foccus of the review is the evolution of medieval Chivalry all through Portuguese Literature. Moments of glory and decadence are examined in the meanwhile of historical and cultural passages. A sonnet from Antero de Quental is the start of the discussion.

Key-words: Literary criticism, ficction, medievalism, renaissance, modernity.

30 Hilário Franco Junior. As utopias medievais, São Paulo, Brasiliense, 1992, p. 144. 